\title{
In vivo and In vitro Protein Digestibility of Formulated Feeds for Artemesia longinaris (Crustacea, Penaeidae)
}

\author{
Analía Verónica Fernández Gimenez ${ }^{1,3^{*}}$, Ana Cristina Díaz ${ }^{2,3}$, Susana María Velurtas ${ }^{3}$ and \\ Jorge Lino Fenucci ${ }^{1,3}$ \\ ${ }^{1}$ Consejo Nacional de Investigaciones Científicas y Técnicas; ${ }^{2}$ Comisión de Investigaciones Científicas; \\ ${ }^{3}$ Departamento de Ciencias Marinas, Facultad de Ciencias Exactas y Naturales, Universidad Nacional de Mar del \\ Plata; Funes 3350, B7602AYL; Mar del Plata - Argentina
}

\begin{abstract}
This study was undertaken to determine the in vivo crude protein apparent digestibility in the prawn Artemesia longinaris, using feeds with $0.25 \%$ of chromic oxide and animal (fish meal, meat and bone meal and squid protein concentrate) and plant (soybean meal) ingredients. Three replicate groups of prawn were fed and the feces were collected. The rate of protein hydrolysis was measured in vitro using midgut gland enzyme extract from the prawns fed the respective feeds and was compared with those found with enzyme extract of wild prawn. The in vivo apparent digestibility coefficients showed significant differences among the feeds $(P<0.05)$. Fish meal feed presented the highest digestibility (92\%); intermediate digestibility (83\%) was found for meat and bone meal feed, and the less digestible feed (63\%) was that containing soybean meal and squid proteins concentrate. No significant differences in the in vitro protein digestibility were found among the experimental feeds. The results indicated the limitation of in vitro enzyme assays and that it should be complemented by in vivo studies.
\end{abstract}

Key words: Prawn; nutrition; protein sources; enzyme assays

\section{INTRODUCTION}

A formulated feed for shrimps can be well balanced and contain all dietary essential nutrients but still it does not produce adequate growth because the nutrients are not readily available. The digestibility of feedstuffs can be affected by the relative ratio of nutrients as well as the presence of inhibitory components in the ingredients (Lee and Lawrence, 1997). Digestibility data are important for the formulation of suitable feeds. Protein is the major and the most expensive ingredient in shrimp feeds and is also a growth limiting. The high amount of protein is also required in shrimp feeds increases the cost and makes the feed into a major expense in shrimp production. Therefore, it is very important to identify the low-cost protein rich ingredients in order to reduce the production costs of shrimp.

Variations in protein requirements in marine shrimp are attributed mainly to different sources of proteins used in the formulations. In recent years, the interest to identify and use alternative protein sources for use within aquafeeds has been increasing (Tacon et al., 1998). Alternate protein ingredients were used to supplement a formulated feed containing fish meal as the main protein source (Divakaran et al., 2000). Soybean meal is the most important source of plant protein, which is currently used to supplement the feeds for

\footnotetext{
* Author for correspondence: fgimenez@mdp.edu.ar
} 
cultured shrimp to reduce the cost. However, it cannot be used as the only source of protein because it lacks certain essential amino acids and contains antinutritional factors such as lectins and proteinase inhibitors (Córdoba Murueta and García Carreño, 2002). Squid protein has been used as a protein source in the feeds and results suggest a favorable response of penaeids (Cruz Ricque et al., 1987; Díaz et al., 1999). This component may, thus, be of economic potential in those areas of the world in which squid can be obtained at low cost. Meat and bone meal is the main by-products of animal slaughterhouse, including meat scraps and trimmings. The quality of meat meal as a protein supplement depends on its production process as well as on the raw material used (Tacon and Akiyama, 1997).

Argentina is one of the main producers of meat and bone meal and soybean meal on a commercial scale. The squid Illex argentinus is an abundant resource in South West Atlantic ocean. The use of these protein sources as part of penaeoid shrimp diets has been shown to be important (Díaz et al., 1999; Díaz and Fenucci, 2002).

In aquaculture, feeding trials have been used to measure the nutritive value of feeds for growth performance; but they are too long and expensive, and the results may be affected by the environmental factors (Lan and Pan, 1993; Wasielesky Jr. et al., 2003). Studies focused to ascertain the nutrients digestibility coefficients usually consist of feeding a feed containing fixed concentrations of a nutrient and an indigestible marker to measure in the feces (Fenucci et al., 1980; Divakaran et al., 2002). Species specific in vitro digestibility methods have been developed using digestive enzymes from the species in question (Lan and Pan, 1993; Ezquerra et al., 1998; Ramos Díaz et al., 2001; Lemos et al., 2004). These methods are usually faster and less expensive than in vivo methods. The in vitro assay using shrimp digestive gland enzyme extract has potential as a promising tool in estimating the digestibility of alternative protein sources. However, digestibility in vivo data are needed to validate data obtained in the digestibility in vitro (Ezquerra et al., 1997). In vivo and in vitro assays must correlate well to predict protein quality (Ezquerra et al., 1997; 1998; Lazo et al., 1998).
The prawn Artemesia longinaris is distributed along the South American coast, from $23^{\circ} \mathrm{S}$ to $43^{\circ} \mathrm{S}$ (Boschi and Gavio, 2005) and is one of the most valuable species in the markets of Brazil, Uruguay and Argentina. Because of the yearly fluctuations of catches, it is important to establish the feasibility of culturing A. longinaris in order to maintain a continuous supply to the market.

Some studies have demonstrated good survival and growth under culture conditions (Fenucci et al., 1983; Petriella et al., 1984), determined the nutritional requirements (Fernandez Gimenez and Fenucci, 2002; Romanos Mangialardo and Fenucci, 2002) and characterized the digestive proteinases in relation to the molting cycle (Fernandez Gimenez et al., 2002). The present study aimed to evaluate the apparent digestibility of protein in formulated feeds for A. longinaris, compared the results with in vitro assays of formulated feeds and protein feed ingredients, and evaluated the possible adaptation of digestive enzymes according to the dietary protein sources.

\section{MATERIAL AND METHODS}

\section{Feed and Feeding Trials}

Artemesia longinaris prawns, weighing $1.3 \pm 0.51$ $\mathrm{g}$, were obtained from a commercial fisherman in the coastal waters of Mar del Plata, Argentina $\left(38^{\circ} \mathrm{S}\right)$.

The treatments consisted of three dry pelletized feeds with $0.25 \%$ chromic oxide as an inert marker. The composition of the formulated feeds were: one of the formulated feeds contained fish meal as main protein source (D1), and the others had meat and bone meal (D2) and soybean meal and squid protein concentrate (D3) in partial substitution of fish meal (Table 1). Feed ingredients were obtained from a local feed manufacturer. Formulations were made according to the chemical composition of the by-products in order to obtain isoproteic and isolipidic diets. The chemical composition of the formulated feeds was confirmed through the proximate analysis (Table 2) according to AOAC (1990). All ingredients were mixed and cold pelleted $\left(<50^{\circ} \mathrm{C}\right)$ by extrusion (Fenucci and Zein-Eldin, 1976). The pellets were oven-dried at $50^{\circ} \mathrm{C}$ for $24 \mathrm{~h}$. 
Table 1 - Ingredient composition of formulated feeds.

\begin{tabular}{|c|c|c|c|}
\hline \multirow{2}{*}{ Ingredient } & \multicolumn{3}{|c|}{ Formulated feed (g/100g dry feed) } \\
\hline & D1 & D2 & D3 \\
\hline Fish meal $^{\mathrm{a}}$ & 48 & 27 & 27 \\
\hline Meat and bone meal ${ }^{\mathrm{b}}$ & - & 23 & - \\
\hline Soybean meal ${ }^{\mathrm{c}}$ & 17 & 17 & 23 \\
\hline Squid protein concentrate ${ }^{\mathrm{d}}$ & - & - & 10 \\
\hline Manioc starch & 20 & 20 & 22 \\
\hline Wheat & 9.25 & 7.25 & 12.25 \\
\hline Fish oil & 2 & 2 & 2 \\
\hline Fish soluble & 2 & 2 & 2 \\
\hline Lecithin & 0.5 & 0.5 & 0.5 \\
\hline Cholesterol & 0.5 & 0.5 & 0.5 \\
\hline Vitamin supplement $^{\mathrm{e}}$ & 0.5 & 0.5 & 0.5 \\
\hline Chromic oxide $^{f}$ & 0.25 & 0.25 & 0.25 \\
\hline \multicolumn{4}{|c|}{ Proximate composition (\% dry matter) } \\
\hline Dry matter & 99.55 & 99.47 & 99.60 \\
\hline Crude protein & 39.30 & 39.80 & 37.20 \\
\hline Total lipid & 8.30 & 7.80 & 7.00 \\
\hline Ash & 6.23 & 5.94 & 5.20 \\
\hline \multicolumn{4}{|c|}{ Agustinier S.A. Mar del Plata, Argentina. } \\
\hline \multicolumn{4}{|c|}{ b Oleochemicals Materia Hnos. S.A.C.I.F. Mar del Plata, Argentina. } \\
\hline \multicolumn{4}{|c|}{ c Melrico S.A. Argentina. } \\
\hline \multicolumn{4}{|l|}{ d Díaz et al. 1999.} \\
\hline
\end{tabular}

All the individuals were kept in 1501 glass aquaria with continuous aeration. Filtered seawater $(5 \mu \mathrm{m})$ was exchanged at a rate of $50 \%$ per day. Prawns were exposed to an $11 \mathrm{~h}$ light-14 $\mathrm{h}$ dark photoperiod, temperature $18^{\circ} \mathrm{C}, \mathrm{pH} 7$, salinity $31 \mathrm{ppt}$. The ammonium concentration never exceeded $0.2 \mathrm{mg} / \mathrm{l}$. All the groups were fed $\mathrm{ad}$ libitum once a day (09:30 h). Formulated feeds were tested in triplicate groups of eight prawns randomly chosen.

\section{Apparent Digestibility}

A seven day period of adjustment to the new conditions and diets was implemented before the beginning of fecal collection. To determine the apparent digestibility for crude protein, before each feeding, feces were collected during 16 days by siphoning and separated from uneaten diet by an appropriate mesh screen. Fecal samples were rinsed with distilled water to eliminate the excess of salts and frozen $\left(-20^{\circ} \mathrm{C}\right)$.

The diets and fecal samples were oven-dried at $50^{\circ} \mathrm{C}$ for $24 \mathrm{~h}$. Proximate analyses of diets (Table 1) and fecal samples were carried out using AOAC methods (1990). The chromic oxide levels in diets and feces were analyzed using a modified colorimetric method (Fenucci, 1981). The levels were measured with a spectrophotometer $(540 \mathrm{~nm})$ (Shimadzu UV-2102 PC, UV-visible Scanning Spectrophotometer) after perchloric acid oxidation and forming a colored complex with diphenylcarbazide (DPC).

The apparent digestibility coefficient (ADC) was estimated according to Fenucci et al. (1980):

$\operatorname{ADC}(\%$ protein digestibility $)=100-\left(\mathrm{I}_{\mathrm{a}} / \mathrm{I}_{\mathrm{b}} \cdot \mathrm{II}_{\mathrm{b}} / \mathrm{II}_{\mathrm{a}}\right.$ $.100)$

Where $\mathrm{I}_{\mathrm{a}=} \% \mathrm{Cr}_{2} \mathrm{O}_{3}$ feed; $\mathrm{I}_{\mathrm{b}=} \% \mathrm{Cr}_{2} \mathrm{O}_{3}$ feces; $\mathrm{II}_{\mathrm{a}=} \%$ protein food; $\mathrm{II}_{\mathrm{b}=} \%$ protein feces

\section{In vitro Digestibility}

To determine if the animals had acclimated to the formulated feed, the changes in protein digestion from the in vitro assay between the midgut gland of wild prawn (control) and of prawn from each treatment were compared at the end of the feeding trial (feeds D1, D2, and D3).

In vitro assays were conducted at the end of the experiment with each formulated feeds (D1, D2 and D3) to determine the protein digestibility in 
the midgut gland of A. longinaris. Specimens were placed on ice and midgut gland were dissected. Samples were immediately stored at $-20^{\circ} \mathrm{C}$. Samples of individuals from the same treatment were pooled. Frozen midgut gland were homogenized in chilled distilled water and centrifuged for $30 \mathrm{~min}\left(10,000 \mathrm{~g}\right.$ at $\left.4^{\circ} \mathrm{C}\right)$. The lipid layer was removed and total soluble protein was evaluated in the supernatants (Bradford, 1976), with albumin from chicken egg white (Sigma) as standard. Total proteinase activity was assayed using $1 \%$ azocasein in $50 \mathrm{mM}$ Tris- $\mathrm{HCl}$ buffer, $\mathrm{pH}$ 7.5 (García Carreño, 1992) (Table 2).

Table 2 - Protein content and specific activity in enzyme extracts of A. longinaris.

\begin{tabular}{lcc}
\hline Treatment & $\begin{array}{c}\text { Protein content } \\
(\mathbf{m g} / \mathbf{m l})\end{array}$ & $\begin{array}{c}\text { Specific activity } \\
(\mathbf{A b s} / \mathbf{m i n} / \mathbf{m g} \text { protein })\end{array}$ \\
\hline D1 & $6.80^{\mathrm{a}}$ & $0.33^{\mathrm{a}}$ \\
D2 & $5.03^{\mathrm{a}}$ & $0.40^{\mathrm{a}}$ \\
D3 & $7.23^{\mathrm{a}}$ & $0.20^{\mathrm{a}}$ \\
Wild & $6.01^{\mathrm{a}}$ & $0.44^{\mathrm{a}}$ \\
\hline Values are means of three replicate analyses. Different superscript letters in the same column show statistical differences \\
$(P<0.05)$.
\end{tabular}

Formulated feeds were finely ground with a mortar and pestle to pass through at 80 mesh screen. The amount of each feed needed to provide $10 \mathrm{mg} / \mathrm{l}$ of crude protein, determined from the proximate analysis (Table 1), was mixed with $50 \mathrm{mM}$ Tris$\mathrm{HCl}$ buffer ( $\mathrm{pH}$ 7.5). A sample of $6 \mathrm{ml}$ supernatant was mixed with a volume of each crude enzyme extract with equivalent units of enzyme activity (Table 2) with vibration at $30^{\circ} \mathrm{C}$ for $0.5,1,1.5$, and $3 \mathrm{~h}$. One mililitre of the mixture was taken for proteolysis, and the process was stopped by the addition of $1 \mathrm{ml}$ of $20 \%$ trichloroacetic acid. The material was filtered and the absorbance $(280 \mathrm{~nm})$ was measured (Lan and Pan, 1993). Three replicates of the same treatment corresponding to the crude enzyme extract were used to measure the enzyme hydrolysis.

\section{Statistical Analysis}

Regression analyses were performed using Origin (4.1) on the actual and predicted chromic oxide values. A correlation coefficient was used to describe the fit of the data on the regression line. ANCOVA was used to test differences among the regression lines. Arc sine transformation was applied to percentages. ANOVA and Student's $t$ test were used to find the differences among the apparent digestibility coefficients and the hydrolysis values among the treatments $(P<0.05)$ (Sokal and Rohlf, 1995).

\section{RESULTS AND DISCUSSION}

Results showed that in vivo apparent digestibility coefficients of protein varied from 63 to $92 \%$ in $A$. longinaris, revealing significant differences among the feeds $(P<0.05)$ (Table 3$)$. The present in vivo digestibility results provided a ranking of protein quality for the feeds. The feed with fish meal as main protein source (D1) was more digestible than the meat and bone meal (D2), and soybean meal plus squid protein concentrate (D3) diets.

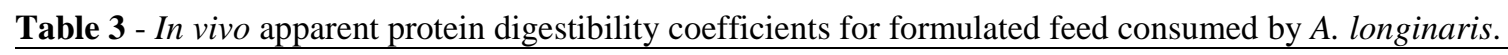

\begin{tabular}{lc}
\hline Treatment & In vivo $(\%)$ \\
\hline D1 & $92.15 \pm 0.435^{\mathrm{a}}$ \\
D2 & $83.83 \pm 3.482^{\mathrm{b}}$ \\
D3 & $63.13 \pm 3.574^{\mathrm{c}}$ \\
\hline
\end{tabular}

Values are means \pm standard error of triplicates.

Percentages with similar superscripts are not significantly different $(P<0.05)$. 
Akiyama et al. (1989) and Ezquerra et al. (1997) reported that chromic oxide seemed to be an appropriate digestibility indicator for penaeid shrimp using a chromic oxide level of $1 \%$. In the present study, its use at a concentration of $0.25 \%$ was adequate because of the amount of feces collected, high digestibility rate, low standard deviation among replicates, and homogeneous mixing of chromic oxide into the formulated feed.

A previous study tried to determine the suitability of various protein sources and optimum protein levels for supporting the growth and survival of the shrimp Pleoticus muelleri (Díaz and Fenucci, 2002). In this work, four formulated feeds with 0 , 20,30 , and $50 \%$ of meat and bone meal to replace fish meal were tested. No significant differences were detected in the final weight gain or survival among the treatments. In A. longinaris, a higher digestibility (83.83\%) was observed with a formulated feed containing 50\% of meat and bone meal in substitution of fish meal (D2). Forster et al. (2003) examined three meat and bone meals and reported similar values of digestibility coefficients for the crude protein in Litopenaeus vannamei ( 81.04 to $87.84 \%)$. The feeding experiments suggested that meat and bone meal could be utilized as a suitable replacement for fish meal in a formulated diet for penaeoid species.

In the present study, apparent digestibility for the formulated feed with soybean meal (D3) were lower to those reported by other researchers for $L$. vannamei (Ezquerra et al., 1997; Divakaran et al., 2000). Lee et al. (1984) and Smith et al. (1985) showed that an adaptative change occurred in the digestive enzymes of $L$. vannamei when shrimp exceeded $10 \mathrm{~g}$, which determined a lower capacity to utilize the animal proteins than smaller shrimps. While shrimp grows up, the protein source is less important and it assimilates similarly both animal and plant proteins. A. longinaris reaches $160 \mathrm{~mm}$ total length (Vinuesa, 2005), the size used in this study corresponded to juvenile prawns $(35 \mathrm{~mm})$. Till now, studies have not been done yet about the aspects related to the ontogenic development of the digestive tract and its relation to feeding habits, and about the digestive physiology that allows determining the biochemical mechanisms used to metabolize the different feeds. The identification of the digestive enzymes and the knowledge of the differences in the digestive potential among the life stages are necessary to formulate the feeds adapted to the physiology of the studied species.

Lemos et al. (2004) found that in Farfantepenaeus paulensis, soybean meal exhibited reduced digestibility and a high degree of protease inhibition. The occurrence of trypsin inhibitor can be attributed to insufficient heat during processing (Swick, 2000, Genovese et al., 2006). Since the ingredients tested were obtained from the feed manufacturers, the poor digestibility observed for soybean meal in A. longinaris would be a reason to increase the quality control of this feedstuff prior to use in shrimp feeds.

The in vitro methods have been applied to the study of digestibility in crustacean (Lan and Pan, 1993; Ezquerra et al., 1997; Lazo et al., 1998). Such methods have potential as screening devices for determining the suitability of feed ingredients for shrimp feeds. In vitro methods based on the $\mathrm{pH}$ monitoring tend to overestimate protein source from plant origin with regards to proteins from animal origin (Haard, 1993). Lan and Pan method (1993) used in Penaeus monodon was chosen, because it confirmed the general pattern described for the apparent digestibilities of typical crustacean feedstuffs for shrimp: casein > wheat gluten >fish meal >soybean meal (Lee and Lawrence, 1997).

Fig. 1 shows the extent of feed protein hydrolysis with extracts from the midgut gland of wild and experimental prawns. No significant differences in the in vitro protein digestibility were found among the formulated feeds as indicated by rate of hydrolysis. At $30^{\circ} \mathrm{C}$ and $\mathrm{pH} 7.5$, all the feeds hydrolysate reached maximal $\mathrm{A}_{280 \mathrm{~nm}}$ within $1.5 \mathrm{~h}$. 


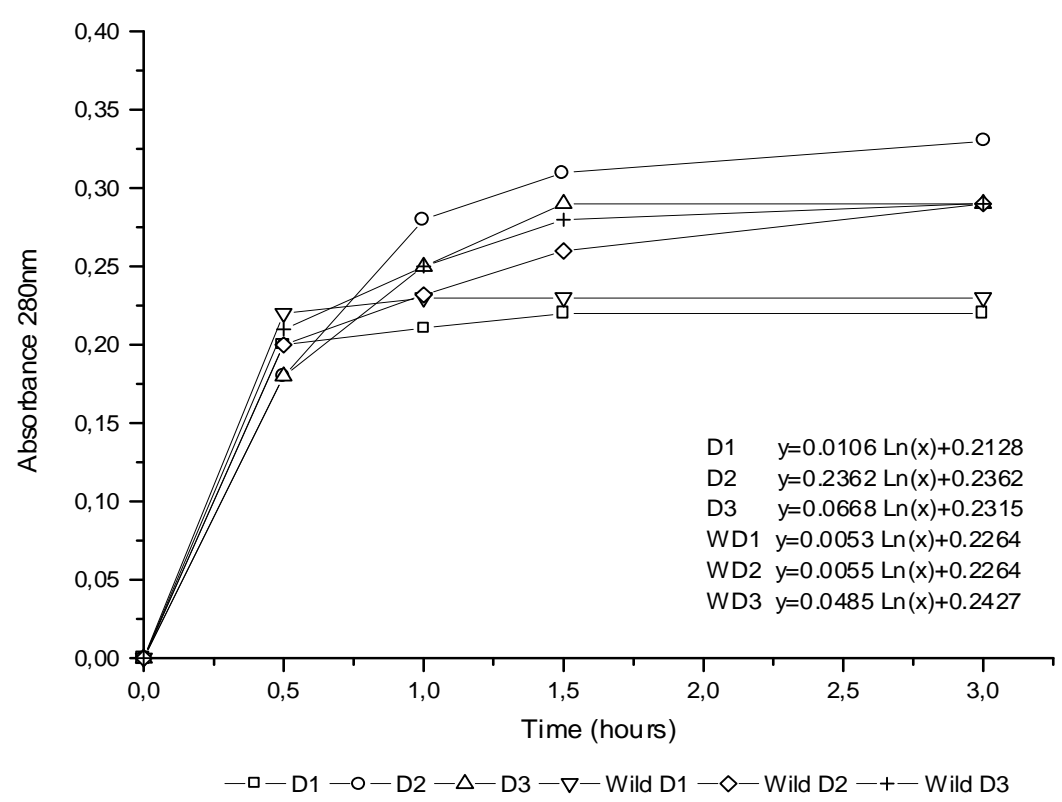

Figure 1 - Protein hydrolysis of formulated feeds (D1, D2 and D3) at $\mathrm{pH} 7.5$ and $30^{\circ} \mathrm{C}$ with crude extract from midgut gland from prawns fed each respective diet and wild A. longinaris.

In the present work, there were significant differences $(P<0.05)$ among the feeds in the apparent protein digestibility of $A$. longinaris. However, there were no differences with in vitro assays. In in vitro methods, the reactions are more drastic than those that occur during the natural digestion of crustaceans and will free nutrients otherwise unavailable (Anderson et al., 1993). Similarly, there is a tendency to overestimate the digestibility of leguminous plants by in vitro methods compared with in vivo methods (Marletta et al., 1992). On the other hand, the results of in vivo methods may be affected by the environmental conditions (temperature, salinity, pH) (Ezquerra et al., 1997).

The present results showed that A. longinaris had a good digestibility for all the formulated feeds tested. The study of digestive enzymes in aquatic animals is a very important preliminary step to obtain valuable information that may be further applied to the development of in vitro digestibility assays. The knowledge of the specific pattern of protein digestion for this prawn could lead to the adequate formulation of feeds.

\section{ACKNOWLEDGEMENT}

This study was funded by a grant PICT/04 $\mathrm{N}^{\circ} 20$ 20209 and $\mathrm{N}^{\mathrm{o}} 21-21290$ from FONCYT (Agencia Nacional de Promoción Científica y Tecnológica), Argentina. Special thanks to Dr. Fernando Luis García Carreño (CIBNOR, BCS, México) for his suggestions to the draft of the manuscript.

\section{RESUMO}

O objetivo do presente trabalho foi determinar a digestibilidade aparente in vivo da proteína bruta de ingredientes de origem animal (farinhas de peixe, osso e carne e concentrado de proteína de lula) e ingredientes vegetais (farinha de soja) em camarões Artemesia longinaris utilizando rações contendo $0,25 \%$ de óxido de cromo. Três grupos de camarões, utilizados como replicatas, foram alimentados e as fezes coletadas. A velocidade de hidrólise da proteína de cada ração foi medida in vitro utilizando extrato enzimático da glândula do intestino médio dos camarões alimentados com a ração correspondente e foi comparado com 
aqueles obtidos com o extrato enzimático de camarões selvagens. Os coeficientes de digestibilidade aparente in vivo mostraram diferenças significativas entre as rações testadas $(\mathrm{P}<0,05)$. A farinha de peixe apresentou a maior digestibilidade (92\%), enquanto valores intermediários de digestibilidade $(83 \%)$ foram encontrados para a farinha de carne e ossos. A ração contendo farinha de soja e concentrado de proteína de lula resultou em menor digestibilidade $(63 \%)$. Não houve diferença significativa entre os valores de digestibilidade in vitro para as rações testadas. Estes resultados indicam a limitação inerente dos ensaios enzimáticos in vitro, os quais poderiam ser complementados com estudos in vivo.

\section{REFERENCES}

Akiyama, D.M., Coelho, S., Lawrence, A.L. and Robinson, T.H. (1989), Apparent digestibility of feedstuff by the marine shrimp Penaeus vannamei Bonne. Nippon Suisan Gakkaishi, 55(1), 91-98.

Anderson, J., Lall, S., Anderson, D. and Mc Niven, M. (1993), Evaluation of protein quality in fish meals by chemical and biological assays. Aquaculture, 115, 305-325.

AOAC (Association of Official Analytical Chemist) (1990), Official methods of analysis of the Association of Official Analytical Chemist, Inc., Arlington.

Boschi, E.E. and Gavio, M.A. (2005), On the distribution of decapod crustacean from the Magellan Biogeographic Province an the Antartic region. Scientia Marina, 69(S2), 195-200.

Bradford, M.M. (1976), A rapid and sensitive method for the quantification of microgram quantities of protein utilizing the principle of protein dye binding. Analytical Biochemistry, 72, 248-254.

Córdoba Murueta, J.H. and García Carreño, F.L. (2002), Nutritive value of squid and hydrolysated protein supplement in shrimp feed. Aquaculture, 210, 371-384.

Cruz Ricque, L.E., Guillaume, J., Cuzon, G. and AQUACOP. (1987), Squid protein effect on growth of four penaeid shrimp. Journal of the World Aquaculture Society, 18(4), 209-217.

Díaz, A.C. and, Fenucci, J.L. (2002), Comparative evaluation of different animal protein source in juveniles of Pleoticus muelleri (Crustacea, Penaeoidea). In-Modern Approaches to the Study of Crustacea, eds. E. Escobar-Briones and F. Alvarez. Kluwer Academic/Plenum Publishers, New York, pp. 75-78.
Díaz, A.C., Fernández Gimenez, A.V. and Fenucci, J.L. (1999), Evaluación del extracto proteico de calamar en la nutrición del langostino argentino Pleoticus muelleri Bate (Decapoda, Penaeoidea). In-Proceeding of the ACUICULTURA '99. World Aquaculture Society, Puerto La Cruz, pp. 184-192.

Divakaran, S., Obaldo, L. and Forster, I.P. (2002), Note on the methods for determination of chromic oxide in shrimp feeds. Journal of Agricultural and Food Chemistry, 50, 464-467.

Divakaran, S., Velasco, M., Beyer, E., Forster, I. and Tacon, A.G. (2000), Soybean meal apparent digestibility for Litopenaeus vannamei, including a critique of methodology. In-Avances en Nutrición Acuicola. Memorias del V Simposium Internacional de Nutrición Acuícola, eds. L.E. Cruz Suarez, D. Ricque-Marie, M. Tapia Salazar, M.A. Olvera Novoa and R. Civera Ceveredo, Mérida, pp. 267-276.

Ezquerra, J.M., García Carreño, F.L. and Carrillo, O. (1998), In vitro digestibility of dietary protein sources for white shrimp (Penaeus vannamei). Aquaculture, 163, 123-136.

Ezquerra, J.M., García Carreño, F.L., Civera, R. and Haard, N. (1997), pH-stat method to predict protein digestibility in white shrimp (Penaeus vannamei). Aquaculture, 157, 251-262.

Fenucci, J.L. (1981), Studies on the nutrition of marine shrimp of the Penaeus. Ph.D. Thesis, Faculty of Department of Biology, University of Houston, Houston, Texas, USA.

Fenucci, J.L., Petriella, A.M. and Müller, M.I. (1983), Estudios sobre el crecimiento del camarón Artemesia longinaris Bate alimentado con dietas preparadas. Contribución Instituto Nacional de Investigación y Desarrollo Pesquero, 424, 1-13.

Fenucci, J.L. and Zein Eldin, Z.P. (1976), Evaluation of squid mantle meal as a protein source in penaeid nutrition. FAO Technical Conference on Aquaculture, Kyoto, Japan 76/S 36, 9.

Fenucci, J.L., Zein Eldin, Z.P. and Lawrence, A.L. (1980), The nutritional response of two penaeid speceis to various levels of squid meal in a prepared feed. Proceedings of the World Aquaculture Society, 11, 403-409.

Fernández Gimenez, A.V. and Fenucci, J.L. (2002), Vitamin E requirement of the prawn Artemesia longinaris (Decapoda, Penaeidae). In-Modern Aproaches to the Study of Crustacea, eds. E. Escobar Briones and F. Alvarez. Kluwer Academic/Plenum Publishers, New York, pp.85-90.

Fernández Gimenez, A.V., García-Carreño, F.L., Navarrete del Toro, M.A. and Fenucci., J.L. (2002), Digestive proteinases of Artemesia longinaris (Decapoda, Penaeidae): partial characterization and relationship with molting. Comparative Biochemistry and Physiology, 132(B), 593-598. 
Forster, I.P., Dominy, W., Obaldo, L. and Tacon, A.G.J. (2003), Rendered meat and bone meals as ingredients of diets for shrimp Litopenaeus vannamei (Boone, 1931). Aquaculture, 219, 655-670.

García Carreño, F.L. (1992), The digestive proteases of langostilla (Pleuroncodes planipes, Decapoda): their partial characterization, and the effect of fed on their composition. Comparative Biochemistry and Physiology, 103B(3), 575-578.

Genovese, M.I., Davila, J. and Lajolo, F.M. (2006), Isoflavones in processed soybean products from Ecuador. Brazilian Archives of Biology and Technology, 49(5), 853-859.

Haard, N. (1993), Digestibility and in vitro evaluation of plant protein for salmonid feed. In-AOCS Monograph Nutrition and utilization tecnology in aquaculture, ed. D.J. Seesa and C. Lim. American Oil Chemists Society: Champaign, pp. 1-29.

Lan, C.C. and Pan, B.S. (1993), In vitro digestibility simulating the proteolysis of feed protein in the midgut gland of grass shrimp (Penaeus monodon). Aquaculture, 109, 59-70.

Lazo, J.P., Romaire, R.P. and Reigh, R.C. (1998), Evaluation of three in vitro enzyme assays for estimating protein digestibility in the pacific white shrimp Penaeus vannamei. Journal of the World Aquaculture Society, 29(4), 441-450.

Lee, P.G. and Lawrence, A.L. (1997), Digestibility. Advances in World Aquaculture, 6, 194-260.

Lee, P.G., Smith, L. and Lawrence, A.L. (1984), Digestive proteases of Penaeus vannamei Boone: relationship between enzyme activity, size and diet. Aquaculture, 42, 235-239.

Lemos, D., Navarrete del Toro, A., Córdoba Murueta, J.H. and García Carreño, F.L. (2004), Testing feeds and feed ingredients for juvenile shrimp Farfantepenaeus paulensis: in vitro determination of protein digestibility and proteinase inhibition. Aquaculture, 239, 307-321.

Marletta, L., Carbonaro, L. and Carnovale, E. (1992), In vitro protein and sulphu aminoacid availability as a measure of been protein quality. Journal of the Science of Food and Agriculture, 59, 497-504.

Petriella, A.M., Müller, M.I., Fenucci, J.L. and Saez, M.B. (1984), Influence of dietary fatty acids and cholesterol on the growth and survival of the Argentine prawn Artemesia longinaris Bate. Aquaculture, 37, 11-20.
Ramos Díaz, R., Miranda Valdés, I. and Molina Segovia, C. (2001), Intake and apparent digestibility of three marine ingredients by white shrimp Litopenaeus vannamei (Boone, 1931). Estudios Oceanológicos, 20, 43-50.

Romanos Mangialardo, R. and Fenucci, J.L. (2002), Effect of different dietary arginine and lysine levels for argentine prawn Artemesia longinaris Bate (Crustacea, Decapoda, Penaeidae). In-Modern Aproaches to the Study of Crustacea, eds. E. Escobar Briones and F. Alvarez. Kluwer Academic/Plenum Publishers, New York, pp.79.

Smith, L., Lee, P.G., Lawrence, A.L.and Strawn, K. (1985), Growth and digestibility by three sizes of Penaeus vannamei Boone: effects of dietary protein level, and protein source. Aquaculture, 46, 85-96.

Sokal, R. and Rohlf, J. (1995), Biometry, the principles and practice of statistics in biological research. $\mathrm{W} \mathrm{H}$ Freeman, New York.

Swick, R. (2000), Soybean meal quality, assessing the characteristics of the major aquatic feed ingredient. Advocate, 5, 46-49.

Tacon, A.G.J. and Akiyama, D.M. (1997), Feed ingredients. Advances of the World Aquaculture, 6, 411-472.

Tacon, A.G.J., Dominy, W.G. and Pruder, G.D. (1998), Global trends and challenges in aquafeeds for marine shrimp. AquaFeed International, 4, 28-35.

Vinuesa, J.H. (2005), Distribución de crustáceos decápodos y estomatópodos del golfo San Jorge, Argentina. Revista de Biología Marina y Oceanografía, 40(1), 7-21.

Wasielesky Jr., A., Bianchini, A., Castaño Sanchez, C. and Poersch, L.H. (2003), The effect of temperatura, salinity and nitrogen products on food. Brazilian Archives of Biology and Technology, 46(1), 135-141.

Received: May 14, 2007; Revised: December 12, 2007; Accepted: April 16, 2009. 